\title{
Assessment of Entrepreneurship in Higher Education: An evaluation of current practices and proposals for increasing authenticity
}

\author{
Track Dinning \\ Liverpool John Moores University
}

\begin{abstract}
Focusing on the assessment of entrepreneurship, this paper adopts a qualitative research approach. Using data collected from twelve face-to-face interviews with enterprise educators, the paper demonstrates how these educators attempt to shift from the use of traditional to more innovative methods of assessment. The paper argues that adopting more innovative and authentic methods is less easy to administer, is time-consuming and more difficult to align with university regulations. Finally, the paper concludes with a set of proposals aligned to academics, students and external practitioners for making entrepreneurship assessment more authentic.
\end{abstract}

\section{Keywords: Higher Education; Assessment; Entrepreneurship.}

\section{Introduction}

In response to government, education and industry (Department of Business, Innovation and Skills (BIS), 2015; The Quality Assurance Agency (QAA), 2018), there is a demand for UK universities to develop employable students who contribute to the 'knowledge-led economy' (Smith and Paton, 2011, p.104). Consequently, entrepreneurship education is more frequently found within higher education (HE) undergraduate degree programmes than it was some ten years ago (Jones and Penaluna, 2013), as it encourages students to practise, develop and demonstrate such skills as creativity, problem-solving and 'making things happen' that are much sought after by employers (Bridgstock, 2009) in today's current highly-competitive environment.

Not unlike the UK, other countries report the need for entrepreneurship education to be part of a graduate's education. For example, Won, Ho and Singh (2007) report on the need for Singapore universities to move towards a knowledge-based approach for entrepreneurship, in order to commercialise home-grown ideas rather than import knowledge from advancing countries. In Nigeria, entrepreneurship education has been made compulsory in universities to address the issue of a decline in graduate employment and a consequent increase in poverty (Ogundele, Akingbade and Akinlabi, 2012). Maritz (2017) suggests that entrepreneurship education is more productive if student-centred and that it should: include, together with the subject knowledge, the competencies needed for employability; foster innovation and the entrepreneurial mind-set (European Commission, 2008).

Pittaway et al., (2009) argue that the focus has been more on pedagogical approaches, to the extent that research on assessment methods is not advancing at the same rate as the changing nature of its universities (UK Higher Education Academy, HEA, 2012). This includes not only the assessment design but also criteria - use of rubric that can limit staff when marking (Bloxham et al., 2015). In the field of entrepreneurship, Jones et al., (2014) advise 
that there remains a lack of scholarship which demonstrates how assessment of student learning actually takes place. With competencies such as creativity and innovation having been associated with entrepreneurship education and graduate attributes (Bacigalupo et al., 2016), Pittaway and Edwards (2012) recommend that this area of assessment be studied further, given that competencies required by employers are at present rarely assessed effectively (Jones and Penaluna, 2013). This issue is not peculiar to the UK: Radloff et al., (2008), in an Australian study, wrote that embedding graduate attributes ought to extend beyond teaching and into assessment. Whilst Ipperciel and El-Atia (2014) report a criteriabased competency model for the assessment of graduate attributes in Canada, it still remains untested. A multi-cultural study across Northern Ireland, Israel and New Zealand concludes that, even with different educational systems in place, the over-arching challenge for all three countries is to avoid the use of one summative-assessment point - for it increases the risk of failure - and instead explore more creative pedagogies for assessment and feedback to support student learning (Gallagher, Hipkins and Zohar, 2012).

Though there is a plethora of publications on assessment that share good practice, Knight and Yorke (2003) argue that they tend to be mainly pragmatic and may lack extensive theoretical foundation. Bloxham and Boyd (2007) aim to rectify this through their work, which draws on current research and translates it into day-to-day practice. Meanwhile, in the field of entrepreneurship, a study by Pittaway et al., (2009) explored the National Council for Graduate Entrepreneurship (NCGE) database of research bibliographies, to find only three papers related to entrepreneurship assessment. It is therefore not surprising that, more recently, education has revived its attention to assessment in this area (Vu and Dall'Alba, 2014), in an attempt to prepare students for a changing employment world. Similarly, in the field of entrepreneurship, there have been recent studies: Duval-Couetil (2013) recommends that this is still an area deserving of study. It is in this context, therefore, that this study will explore assessment methodologies used by a group of enterprise educators working in UK universities. In particular, it will consider innovative practices used and challenges faced by educators in this area.

\section{Assessment practice and challenges}

According to Bloxham and Boyd (2007), assessment needs to be challenging and demanding, so that the students exhibit a deeper level of learning; it also needs to have a focus on learning rather than just be a measure for learning (Medland, 2014). Equally, it is important both that teaching and assessment are integral and promote a package of learning to the students and that assessment is not just viewed as an afterthought in curriculum development, but is integral to learning (HEA, 2012, Medland, op.cit.). In most cases, students consider assessment to be the central focus of their activities over the actual course (James, McKinnis and Devlin, 2002) leaving academics with the challenge of how to engage students in 'assessment for learning' beyond the subject content being assessed. Brown (2015) would argue that curriculum designers must explore not only effective approaches to teaching and learning but also fit-for-purpose methods of assessment, so that learning is continuous between the classroom and assessment (Vu and Dall'Alba, op.cit, Boud and Soler, 2015) and so that students can identify how assessment links to relevant activities (Litchfield and Dempsey, 2015).

Traditional assessment methods that rely on memorisation and reproduction (like formal, timeconstrained, unseen exams) are thought to promote the surface-learning approaches taken by 
students rather than a deeper learning and understanding of course material (Kearney, 2013; Race, 2015). Struyven, Dochy and Janessens (2005) suggest that such assessment methods assess the students' memories, whilst more effective methods have the potential to measure qualities and skills that enable students to show what they have acquired from the course material and how they can apply it to live contexts. The challenge for academics is to make the assessment manageable, yet at the same time ensure it translates into the discipline of practice and extends the learning experience (Brown, 2015) in the context of the discipline (Boud and Soler, op.cit.). One way of approaching this is through real-world tasks for the assessment that allow the students to continue their learning; such tasks are described by Brown (op cit., 2015) as authentic. This type of assessment is widely regarded as being more valued than traditional assessment, as it encourages students to engage practically with the material in order to learn through application and develop their critical-thinking and problemsolving skills (Research Starters, 2014; Litchfield and Dempsey 2015). In addition, it has the potential to enhance students' learning in preparation for the real world ( $\mathrm{Vu}$ and Dall'Alba, op.cit.). Looking beyond entrepreneurship education in the UK, Tan and $\mathrm{Ng}$ (2006) report on problem-based learning in a Singapore university being used as a strategy for entrepreneurship education, where the students are assessed on their critical thinking in the process of developing solutions, journal entries and the ability to work in a team.

It is this non-traditional type of assessment that is becoming favoured in the field of entrepreneurship, as traditional forms of assessment 'about' entrepreneurship adopt more theoretically-based assessment methods associated with business models and start-ups rather the skills (Rae, 2007). Jones and Penaluna (op. cit.) challenge the use of the traditional plan as a means of assessment: whilst they do not dismiss the use of the business plans for assessment, they suggest that being part of a coordinated mentorship programme would serve students better, since developing a stand-alone business from scratch can leave students disconnected with reality (Falkang and Albeti, 2000), especially if the plan remains untested at the point of marking.

More recently, assessing 'for' entrepreneurship adopts more practical methods (Pittaway and Edwards, 2012). For example, tasks where students consider the planning of business ideas from concept to inception allow them to develop entrepreneurial skills and competencies in what is considered to be a valued and authentic assessment approach (Honig, 2004); better still is assessing 'through' entrepreneurship, where students are able to run a real company in a safe environment, with the focus being on learning by doing (Pittaway and Cope, 2007). Falkang and Albeti (2000) further suggest that assessing through entrepreneurship must involve some in-course features to train students in the entrepreneurial skills that employers seek. Pittaway and Edwards (op.cit.) conclude that, whilst there appear to be some innovative methods in use, the assessment practice of most entrepreneurship educators still includes mainly traditional approaches. This study is set to challenge this notion through interviews with enterprise educators.

\section{Methodology}

This study used a qualitative design with individual interviews as the method of data collection. Full ethical approval was secured from the university prior to any approach to participants. 


\section{Research method and participants}

Through a process of purposive sampling, participants were recruited from a population of UKbased enterprise educators attending an assessment workshop at an International Enterprise Educators Conference. Potential participants were contacted via email. This correspondence included full details of the research and a consent form for participants to complete and return, to indicate their willingness to take part. One criterion for inclusion of subjects in the research was their self-identification as enterprise educators. Upon receiving the consent form, the researcher set up interviews with the twelve volunteering participants $(n=12)$. Interviews took place either in the researcher's or participant's office or on Skype. Using a semi-structured interview approach, all interviews lasted between thirty-eight and fifty-five minutes and were conducted by a single researcher to ensure research consistency (Gratton and Jones, 2010). The purpose of the interviews was to gather from the participants examples of the most interesting summative assessments that they had used in the field of enterprise/entrepreneurship. The following questions were posed to start the discussion:

- What type of assessments do you use or have you used when assessing entrepreneurship? Please could you give details of one summative assessment you have used that you deem to be the most innovative in your practice.

- Did the assessment assess the skills of entrepreneurship or the subject? Most participants mentioned creativity in their responses, so a further question was asked about how they assessed the skill.

- Did the students seem to enjoy this type of assessment?

- How manageable did you find the assessments and did you have any problems with them?

- What are your views of the future of assessment in this field?

All interviews were audio-recorded, allowing for files to be downloaded and then transcribed verbatim, using a professional transcription service.

\section{Data analysis}

Interviews were transcribed and key findings relating to the study's objectives were amassed through an interpretive thematic analysis that followed the staged process advocated by Braun and Clarke (2006). Following transcription, each account was read and re-read to familiarise the researcher with responses. The initial codes were systematically generated via the annotation of key words and associated phrases. Themed data was then reviewed and refined to ensure that the collated extracts for each theme not only appeared to form a coherent pattern but also reflected the entire data set accurately. The use of the themes then guided the discussion, with any definitions being clearly outlined and final pertinent data selected and related back to the study objectives which had been originally derived from the investigatory literature discussed above.

\section{Results and discussion}

The findings of this study show that assessment methods used in the field of entrepreneurship education tend to be a mix of traditional and non-traditional types of assessment. It would appear that enterprise educators like to explore non-traditional methodologies for assessment, but sometimes are confined to using more traditional methodologies, owing to time and class- 
size constraints. This discussion will first look at the skills competencies that participants listed within the interviews and then explore the specificity of assessments that participants considered to be their most innovative features.

\section{Skills and competencies}

All twelve participants reported that the assessments described in the interviews were designed to foster students' skills, personal competencies and attributes, and their development through the use of reflection, all in accordance with assessment through entrepreneurship (Rae, 2007). Five of the participants elaborated on the skills and attributes they sought and specifically mentioned such aspects as self-efficiency, resilience and ability to cope with changing environments that they aimed to develop within students and to reward with marks. Educator 7 remarked:

"I don't get too worried about the skills side of things, it's more the attitude. Most of the skills we talk about are not complicated; I think it's more about someone having the passion to do something"

In addition, all participants reported that students' being creative was a central part of their assessment in some way, although, when pressed to discuss how they actually assessed creativity, there was a mixed response. Educator 10 suggested:

"Students may be able to come up with plenty of ideas but I would question if students were able to justify their choice of idea"

(or, as Educator 2 queried, "whether their idea will even work"). Educator 6 said that he always got students "to reflect on their process of being creative, how they generated the ideas and how they chose one to use". Four of the participants said that they did not specifically aim to teach creativity or even use that term: instead they got students to 'unlock' the problems and come up with the solutions. "The assessment of creativity is a difficult one, so I simply don't do it!" (Educator 2). These findings are very much in line with those of Jones and Pennaluna (2013, op. cit.), who proposed that, within the business context, terminology such as 'creativity' and 'innovations' was very rarely used, never mind assessed. It is apparent that being creative and having the ability to develop solutions to subject-related problems is something that all enterprise educators are looking for in their students, but there are no shared or readily-describable ways to assess it.

\section{Methods and approaches}

When presented with a list of different types of assessment prepared in advance by the researcher, all participants said they had used most at some point. The methods included using case studies, scenario-planning, portfolios, blogs, role play, YouTube, business plans and games and presentations. Educators 2 and 3 both suggested that they used essays to assess the theoretical side of the subject of entrepreneurship. This accords with Rae (2007), who suggests that essays can be useful when wanting to assess students' learning about entrepreneurship. Exams, it was suggested, similarly have value. Educator 3 added that their department used exams because of large class sizes. These two participants both acknowledged that such traditional formats can lend themselves to surface approaches and do not necessarily measure the qualities and skills that the course requires (Dochy and Janessens, 2005). They recognised that a move towards more appropriate methods would 
allow for the students' skills and competencies to be developed and, potentially, assessed. However, restrictions imposed by the university framework sometimes affected their choice of assessment.

\section{Commonly-used methods:}

\section{Business plans}

The results also demonstrated that there is still considerable reliance on business plans as a method of assessment, which is suggested to be an assessment 'for' entrepreneurship method (Pittaway and Edwards 2012). Educator 1 commented:

"We use a business plan in the assessment due to the large numbers on the programmes as it's easier to administer and work within the university framework."

Five participants said they used a business plan as part of their module activity and assessment, although Educator 8 indicated that the business plan itself was not the focus of the assessment; that was rather the defence of the plan in front of a panel of entrepreneurs, making it more authentic. Furthermore, Educators 2 and 3 both acknowledged that their decision to use the business plan in its traditional format was in response to the large numbers in the groups being taught. Meanwhile, Educators 11 and 12 stated that their reasons for the inclusion of assessed business plans were rather that areas such as marketing, finance and market reasons could, within them, be reported and demonstrated in a coherent and integrated manner. Educators 1 and 10 both explained that in the past they had used business plans, but felt they were nowadays very much outdated, as students could pass the assignment without really learning anything from the assessment task; this accords with the work of Penaluna and Penaluna (2009). Educator 1 said that she had started to utilise startup tools such as the 'Business Model Canvas' (Ries, 2011), which is a business template designed for supporting the development of new or existing businesses. She found this to be a more exciting method to use with students, adding:

"I prefer to use evidence-based entrepreneurship, for example, techniques to look at customer discovery, so rather than [just] a business plan, you have a set of hypotheses that you test with customers, which is far more valuable that just looking at facts about the marketplace"

Educator 4 said that, though their department used a traditional business plan as part of the assessment, canvas models deployed within their teaching aided the students' understanding of their business. Furthermore, as Jones and Pennaluna (2013) suggest, the business plan approach would be better placed alongside a mentorship programme. Educator 4 said that, as part of her module, she used external entrepreneurs (Carey and Matley, 2007) to mentor the students and, though this strategy did not form part of the assessment, the entrepreneurs brought a lot of value to the module and the students' plans. So, whilst the use of a business plan might be deemed assessing 'for' entrepreneurship and still a more traditional method of assessment, it is evident that a change in the focus of the assessment can result in the adoption of a more authentic, 'through' method of entrepreneurship. 
Presentations

All participants reported using some form of presentation as part of their assessment - though the format of these varied between respondents - and, as with the business plans, attempts by academics to develop authentic assessment were more evident. Variations on the presentation approach included the use of: a traditional 'business pitch' idea; creating a video pitch for a client; preparing an advertisement or TV show for their product/service; role play; pitching for crowd funding; pitching to entrepreneurs. These types of assessment are more closely linked to the real-world experience which Meyers and Nulty (2009) identify as one of the design points for authentic assessment. Educator 6 reported on his attempts to introduce the use of 'flash mobs', but found it difficult to manage in line with university assessment regulations. There was also a general feeling that students enjoyed this type of assessment as it gave them opportunities to be creative in the production of the presentation and that this, by its nature, was a more authentic way to assess. Educator 10 reported using an online crowdfunding site, where a traditional business pitch is applied, but where there is artificial money that the students allocate to the best pitches. The system is set up to represent a local economy, so not all groups will receive the required funding to launch their businesses; the final part of the assessment is a reflection on what happens next, given the result of the crowd-funding exercise. According to the educator, this assessment strives to develop students' entrepreneurial decision-making and to measure the extent to which they think and learn within the assignment. A further example of variation on presentation was the use of 'Pitch Deck', which is a twelve-slide presentation giving an overview of your business.

\section{Assessed reflection}

Within this study it is clear that reflection also plays an important role in the assessment of entrepreneurship, with ten out of twelve educators using it at some point. For most, it was incorporated only as part of the module assessment alongside other approaches. Educators indicated that, in their view, reflection should not merely be required at the end of the assessment, but take place throughout; it could also play a part in formative assessment. Thus, students have opportunities to reflect, take action, learn and reflect again, cyclically within one assessment. Educator 9 gave an example of an assignment where students reflect upon their choices of target markets and product as a result of speaking to potential customers. They decide whether to go with their product as it stands, make slight changes to it or develop a completely new product. Five of the twelve participants were very clear that it is the journey and experience that needs credit through assessment, something possible, they argued, through reflection.

"we need to assess how students reflect on their actions following their reflections" (Educator 10)

Educators indicated that they considered that reflection needs to be incremental, iterative and formative, thus making the whole assessment a learning journey for the student and more authentic (Brown, op. cit.), with students reflecting upon their learning rather than merely demonstrating it (Duval-Couetil, 2015). 


\section{Further innovative approaches}

In general, educators reported constraints of class size, resourcing and their university regulations when attempting to be more innovative in their assessment of entrepreneurship. Educator 5 suggested that she was currently considering ways in which a student could come up with her own assessment, but one which would still allow her to fit to the university assessment regulations; such a strategy has been undertaken in the past, through a learning contract (Knowles, 1986). This requirement for regulatory conformance, alongside timeconstraints and group size, seemed to be the main challenges to developing more innovative and authentic assessment in this area, although one participant argued that these should not be a barrier to innovation:

"Innovation will always be time consuming the first time you do it but if you get it right and plan ahead, it should not be a barrier" (Educator 1)

\section{Analysis of findings}

The following diagram (Figure 1) is a conceptual mapping of the assessment approaches described by educators in this study; they are mapped against the ease to implement and level of authenticity. The analysis makes the assumption that the more authentic the assessment is, the less traditional the method, whilst the ease to administer and conform to university framework is inferred through these research findings.

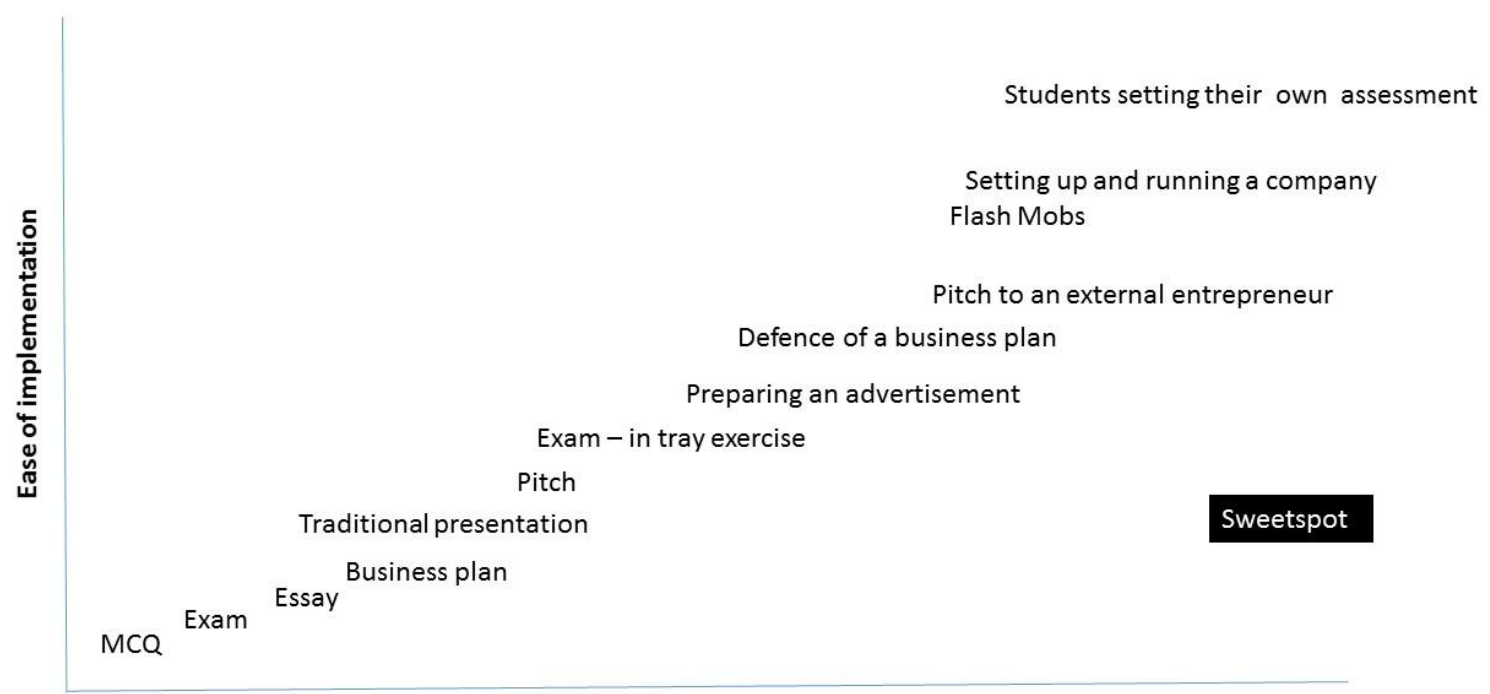

Level of authenticity

Figure 1: Conceptual map of assessment approaches against educators' and authors' perceived conformance to university framework

This diagram is designed to help curriculum designers to make sensible choices about assessment-method selection, by exploring the trade-offs between ease of implementation and levels of authenticity. This evidence-informed analysis by the researcher proposes that 
there is a potential 'sweet spot' where authenticity is high and where any challenges afforded by university regulatory constraints can be reasonably readily overcome. So, while multiplechoice questions can be regarded as low in terms of innovation, they are relatively easy to align with university systems and there is still some case value for their use in providing rapid feedback relatively easily. Where aligning an innovative approach with university systems can seem highly challenging, there is value in dedicating time and effort to finding solutions to the quality-assurance hurdles. The challenge for educators is to find ways the better to integrate innovative assessment with university systems and to make more easily-integrated assessment more authentic; for example, by involving employers and other externals in assessments such as pitches (though such strategies themselves provide challenges in terms of inter-assessor reliability) or by using innovative formats within unseen exams, such as the in-tray exercises advocated by Brown (2016), which present examinees with authentic dilemmas and tasks within conventional time-constrained settings and which require considerably more application of knowledge than straightforward recall. This study has challenged the notion that the assessment practice of most entrepreneurship educators is mainly traditional (Pittaway and Edwards 2012) and has provided clear evidence that some enterprise educators try to operate outside the boundaries of traditional approaches to assessment even though they are constrained by resources, class size and university assessment regulations. Further research is required in this area - in particular the transferability of these assessment methods across different disciplines - as is further exploration of assessment design to create assessments that can be positioned in and around the 'sweet spot'.

\section{Conclusions}

Enterprise educators in this study are clearly seeking to find ways to be more authentic in their assessments while managing regulatory requirements, with the suggestion that this area clearly needs extensive further study. Assessment of entrepreneurship clearly needs to be part of a much wider dialogue on assessment, to ensure that assessment is a means of learning, not just a final summation of it. This research demonstrates that, notwithstanding constraints and challenges, innovation in the classroom and in assessment is, in many cases, at the heart of the enterprise educators' practice and that dissemination and discussion of good practice is valuable to the academic community as a whole. The paper concludes with some recommendations for future practice in this area for academics, students and external practitioners, as well as in relation to the assessment design itself.

It can be argued that academics need:

- to explain fully to students the process and the authentic nature of the assessment;

- to provide dialogic opportunities to discuss the purposes of assessment within a module (that is, is entrepreneurship demonstrated about or for or through the assessed practice?);

- to develop the uses of technology to support effective assessment (for example, in giving fast and developmental feedback);

- to ensure that assessment activities and tasks link back constructively to learning outcomes;

- to consider the extent to which students can be involved through negotiation in designing the format and outcomes of assignments; 
- to achieve clarity for all stakeholders where academic content can be used to underpin practice;

- to customise assignments, where possible, to fulfil the students' individual needs.

and that students need:

- to adopt an active approach to their own learning and develop their assessment literacy, so that they understand the processes, practices and systems of assessment on their programmes;

- to work in partnership with their assessors by seeking out, taking note of and using formative feedback to ensure enhancement of their practices and outcomes;

- to recognise the value of diverse assessment approaches and methods, embracing sometimes unfamiliar or challenging tasks as a means of helping them to evidence their entrepreneurial capability;

- to think beyond the mark given for an assignment by being reflective about their learning and self-development as experienced through assessment.

and that external practitioners need:

- to familiarise themselves with university systems and processes, so that the judgements they make align with requirements to maintain standards appropriate to the level of the ward;

- to work closely in partnership with the academics teaching and assessing on the programme, to ensure shared understanding and to bring to assignments the authenticity that derives from live cases and real-world scenarios;

- to engage with assessment criteria fully, so that their assessment decisions are based on evidence of achievement rather than 'gut-reaction';

- to be unafraid to challenge their academic colleagues and the university when they feel that assessment tasks could be made more authentic.

and that assessment design needs:

- to make good use of external entrepreneurs and real customers at all stages of assessment, providing comments on task design, proposing ways of making assessment contexts more realistic, involving them in assessing and giving feedback to students and engaging with quality assurance and enhancement (for example, by reviewing and analysing student feedback on assessment);

- to ensure integral assignment creditation of the learning journeys of students, allowing them to customise their assignments by bringing into their work relevant prior experiences;

- to seek ways to ensure that feedback is informative, formative, and transformative, with the potential to change a student's future behaviour and to build their entrepreneurial capabilities;

- to offer reflective opportunities for all stakeholders, so that assignments are continuously refreshed and align with requirements of potential future workplaces. 
Adopting and implementing these recommendations have the potential to transform substantially the assessment of entrepreneurship in global HE. The benefits of doing so persistently and robustly are arguably so powerful that the inevitable hard work and resilience needed to bring them about is demonstrably justified.

\section{Reference list}

Bacigalupo, M., Kampylis, P., Punie, Y. and Van den Brande, G. (2016) EntreComp: The Entrepreneurship Competence Framework. JRC Science Policy Report. Luxembourg: Publications Office of the European Union. Available at: https://ec.europa.eu/jrc/en/publication/eur-scientific-and-technical-researchreports/entrecomp-entrepreneurship-competence-framework (Accessed: 24 September 2018).

Biggs, J. and Tang, C. (2011) Teaching for Quality Learning at University (4th edition). Buckingham: SRHE and Open University Press.

Bloxham, S. and Boyd, P. (2007) Developing effective assessment in higher education: a practical guide. Open University Press: McGraw-Hill.

Bloxham, S., Deouter, B., Hudson, J. and Price, M. (2015) 'Let's stop the pretence of consistent marking: exploring the multiple limitations of assessment criteria.' Assessment and Evaluation in Higher Education, 41(3), 466-481. Available at:

https://www.tandfonline.com/doi/pdf/10.1080/02602938.2015.1024607 (Accessed: 25

September 2018).

Boud, D and Soler, R. (2015) 'Sustainable assessment revisited'. Assessment and Evaluation in Higher Education,41(3), 400-413. Available at:

https://www.tandfonline.com/doi/abs/10.1080/02602938.2015.1018133?journalCode=caeh20( Accessed: 25 September 2018).

Bridgstock, R. (2009) 'The graduate attributes we've overlooked: enhancing employability through career management skills.' Higher Education Research \& Development, 28(1), 31-44. Available at: https://www.tandfonline.com/doi/abs/10.1080/07294360802444347 (Accessed: 25 September 2018).

Biggs, J. (2003) Teaching for Quality and Learning at University. London: Open University Press.

Brown, S. (2015) 'Authentic assessment: using assessment to help students learn.'RELIEVE, 21(2). Available at: https://www.uv.es/RELIEVE/v21n2/RELIEVEv21n2 M4eng.htm (Accessed: 25 September 2018).

Brown, S. (2015) Learning, teaching and assessment in higher education: Global Perspectives, London: Palgrave-MacMillan.

Carey, C. and Matley, H. (2011) 'Emergent issues in enterprise education: the educator's perspective.' Industry and Higher Education, 25(6), 441-450. Available at:

http://journals.sagepub.com/doi/abs/10.5367/ihe.2011.0067(Assessed: 25 September 2018). 
Department for Business, Innovation and Skills (2015) Understanding employers' graduate recruitment and selection practices: main report. BIS Research paper No.231. Available at: https://assets.publishing.service.gov.uk/government/uploads/system/uploads/attachment data /file/474251/BIS-15-464-employer-graduate-recruitment.pdf (Accessed: 27 September 2018).

Duval-Couetil, N. (2013) 'Assessing the impact of entrepreneurship education programs:challenges and approaches.' Journal of Small Business Management, 51(3), 394409. Available at: https://onlinelibrary.wiley.com/doi/abs/10.1111/jsbm.12024 (Assessed: 26 September 2018).

European Commission (2008) Final Report of the expert group: Entrepreneurship in higher education, especially within non-business studies. Luxembourg: Publications Office of the European Union. Available at: https://ec.europa.eu/growth/content/final-report-expert-groupentrepreneurship-higher-education-especially-within-non-business-0 en (Accessed: 27 September 2018).

Falkang, J. and Alberti, F. (2000) 'The assessment of entrepreneurship education.' Industry and Higher Education,14(2), 101-108. Available at: http://journals.sagepub.com/doi/abs/10.5367/000000000101294931 (Accessed: 25 September 2018).

Gallegher, C., Hipkins, R. and Zohar,A. (2012) 'Positioning things within national curriculum and assessment systems from Israel, New Zealand and Northern Ireland.' Thinking Skills and Creativity, 7, 134-143. Available at: https://www.sciencedirect.com/journal/thinking-skills-andcreativity/vol/7/issue/2 (Accessed: 26 September 2018).

Gibb, A. (2002) In pursuit of a new enterprise and entrepreneurship paradigm for learning:creative destruction, new value, new ways and doing things and new combinations. International Journal of Management Review,4(3). Available at:

https://onlinelibrary.wiley.com/doi/abs/10.1111/1468-2370.00086 (Accessed: 25 September 2018).

Gratton, C. and Jones, I. (2010) Research methods for Sport Studies. Oxon: Routledge.

Litchfield, B.C. and Dempsey, J.V. (2015) 'Authentic assessment of knowledge, skills and attitudes.' New Directions for Teaching and Learning, 142. 65-79. Available at: https://onlinelibrary.wiley.com/doi/full/10.1002/tl.20130 (Accessed: 24 September 2018).

Higher Education Academy (2012) A Marked Improvement: transforming assessment in higher education. York: Higher Education Academy.

Jones, C. (2006) 'Enterprise education: revisiting Whitehead to satisfy Gibbs.' Educationand Training, 48(5), 336-347. Available at:

https://www.emeraldinsight.com/doi/full/10.1108/00400910610677045 (Accessed: 25

September 2018).

Jones, C., Matlay, H., Penaluna, K. and Penaluna, A. (2014) 'Claiming the future of enterprise education.' Education and Training, 56(8/9), 764-775. Available at:

https://www.emeraldinsight.com/doi/abs/10.1108/ET-06-2014-0065 (Accessed: 26 September 2018). 
Jones, C. and Penaluna, A. (2013) 'Moving beyond the business plan.' Education and Training. 55(8/9), 804-814. Available at: https://www.emeraldinsight.com/doi/full/10.1108/ET06-2013-0077 (Accessed: 25 September 2018).

Honig, B. (2004) 'Entrepreneurship education: towards a model of contingency-basedbusiness planning.' Academy of Management Leaning and Education, 3(3), 258-273. Available at: https://journals.aom.org/doi/10.5465/amle.2004.14242112 (Accessed: 25 September 2018).

Ipperciel, D. and EIAtia, S. (2014) 'Assessing graduate attributes: Building a criteria -based competency model.' International Journal of Higher Education, 3(3), 27-38. Available at: https://files.eric.ed.gov/fulltext/EJ1067490.pdf (Accessed: 25 September 2018).

James, R., McInnis, C., and Devlin, M. (2002) Assessing learning in Australian universities: ideas, strategies and resources for quality in students assessment. The University of Melbourne, Centre for the Study of Higher Education. Available at: http://dro.deakin.edu.au/view/DU:30006784 (Accessed: 25 September 2018).

Kearney, S. (2013) 'Improving Engagement: The Use of Authentic Self and Peer Assessment for Learning to Enhance the Student Learning Experience.' Assessment and Evaluation, 38(7), 875-891. Available at:

https://www.tandfonline.com/doi/abs/10.1080/02602938.2012.751963 (Accessed: 25

September 2018).

Klapper, R.G. and Farber, A. (2016) 'In Alain Gibb's footsteps: Evaluation

alternateapproaches to sustainable enterprise education.' The International Journal of Management

Education, 14, 422-439. Available at:

https://www.sciencedirect.com/science/article/pii/S1472811716300556 (Accessed: 25

September 2018).

Knight, P. and Yorke, M. (2003) Assessment, learning and employability. London: Mc Graw Hill Education.

Knowles, M.S. (1986) Using learning contracts: Practical approaches to individualizing and structuring learning. New Jersey: Jossey-Bass.

Litchfield, B.C. and Dempsey, J.V. (2015) 'Authentic assessment of knowledge, skills andattitudes.' New Directions for Teaching and Learning, 142, 65-79. Available at: https://onlinelibrary.wiley.com/doi/full/10.1002/tl.20130 (Accessed: 25 September 2018).

Matley, H. (2006) 'Researching entrepreneurship and education: Part2: what is entrepreneurship education and does it matter?' Education and Training, 48(8/9), 704-718. Available at: https://emeraldinsight.com/doi/full/10.1108/00400910610710119 (Accessed: 25 September 2018).

Maritz, P.A. (2017) 'llluminating the black box of entrepreneurship education programmes: Part 2.' Education + Training, 59(5), 71-482. Available at:

https://www.emeraldinsight.com/doi/full/10.1108/ET-02-2017-0018 (Accessed: 25 September 2018). 
Meyer, J. and Land, R. (2013) Overcoming barriers to students understanding: Threshold concepts and troublesome knowledge. London: Routledge.

Meyers, N. and Nulty, D. (2009) 'How to use (five) curriculum design principles to align authentic learning environments, assessment, students' approaches to thinking and learning outcomes.' Assessment and Evaluation in Higher Education, 34, 565-577. Available at: https://eric.ed.gov/?id=EJ865458 (Accessed: 26 September 2018).

Medland, E. (2014) 'Assessment in higher education: driver, barriers and directions for change in the UK.' Assessment and Evaluation in Higher Education, 41(1), 81-96. Available at: https://srhe.tandfonline.com/doi/full/10.1080/02602938.2014.982072\#.W6vNP0xFyUk (Accessed: 26 September 2018).

Ogundele, O.J.K., Akingbade, W.A. and Akinlabi, H.B. (2012) 'Entrepreneurship training and education as strategic tools for poverty alleviation in Nigeria.' American International Journal of Contemporary Research, 2(1), 148-156. Available at:

http://scholarpublishing.org/index.php/ABR/article/view/345 (Accessed: 26 September 2018).

Quality Assurance Agency (2012) Enterprise and Entrepreneurship: Guidance for UK.higher education providers. London: The Quality Assurance Agency.

Penaluna, A. and Penaluna, K. (2009) 'Assessing creativity: drawing from the experience of the UK's creative design educators.' Education and Training, 51(8/9), 718-732. Available at: https://www.emeraldinsight.com/doi/full/10.1108/00400910911005262 (Accessed: 26

September 2018).

Penaluna, K., Penaluna, A. and Jones, C. (2012) 'The context of enterprise education: insights into current practice.' Industry and Higher Education, 26(3), 163-175. Available at:

http://journals.sagepub.com/doi/10.5367/ihe.2012.0098 (Accessed: 26 September 2018).

Pittaway, L. and Cope, J. (2007) 'Simulating entrepreneurial learning: integrating experiential and collaborative approaches to learning.' Management Learning, 3(2), 221-233. Available at: http://journals.sagepub.com/doi/abs/10.1177/1350507607075776 (Accessed: 26 September 2018).

Pittaway, L., Hannon, P., Gibb, A. and Thompson, J. (2009) 'Assessment practice inenterprise education.' International Journal of Entrepreneurship Behaviour and Research,15(1), 71-93. Available at: https://www.emeraldinsight.com/doi/abs/10.1108/13552550910934468 (Accessed: 26 September 2018).

Pittaway, L. and Edwards, C. (2012) 'Assessment: examining practice in entrepreneurship education.' Education and Training, 54(8/9), 778-800. Available at:

https://www.emeraldinsight.com/doi/full/10.1108/00400911211274882 (Accessed: 26

September 2018)

Race, P. (2014) Making learning happen (3rd edition). London: Sage.

Race, P. (2015) The Lecturer's Toolkit: A practical guide to assessment, learning and teaching (4th edition). London: Routledge. 
Radloff, A., De La Harper, B., Dalton, H., Thomas, J. and Lawson, A. (2008) 'Assessing graduate attributes: Engaging academic staff and their students.' Conference proceedings: ATN Assessment, Engaging students in assessment. Adelaide, Australia. Available at: https://researchbank.rmit.edu.au/view/rmit:2524 (Accessed: 26 September 2018).

Rae, D. (2007) Entrepreneurship: from opportunity to action. London: Palgrave Macmillan.

Rae, D. (2010) 'Universities and enterprise education: responding the challenges of a the new era.' Journal of Small Business and Enterprise Development, 17(4), 591-606. Available at: https://www.emeraldinsight.com/doi/full/10.1108/14626001011088741 (Accessed: 26

September 2018).

Reis, Reis, E. (2011) The Lean Startup. St Ives: Portfolio Penguin.

Research Starters (2014) Authentic assessment. ESBCO Research Starters. New York: Great Neck publishing New York.

Robinson, P. and Josien, L. (2014) 'Entrepreneurial education: using "the challenge" in theory and practice.' Journal of Entrepreneurship Education, 17(2), 172-185. Available at:

https://www.abacademies.org/articles/jeevol1722014.pdf (Accessed: 26 September 2018).

Sadler, R. (2015) 'Three in-course assessment reforms to improve higher education learning outcomes.' Assessment and Evaluation in Higher Education, 41(7), 1081-1099. Available at: https://www.tandfonline.com/doi/full/10.1080/02602938.2015.1064858 (Accessed: 26 September 2018).

Smith, A.M.J. and Paton, R.A. (2011) 'Delivering enterprise: A collaborative international approach to the development, implementation and assessment of entrepreneurship.' International Journal of Entrepreneurial Behaviour and Research,17(1), 104-118. Available at: https://www.emeraldinsight.com/doi/abs/10.1108/13552551111107534 (Accessed: 26

September 2018).

Tan, S. and Ng. C.K. (2006) 'A problem-based learning approach to entrepreneurship education.' Education and Training, 48(6), 416-428. Available at: https://www.emeraldinsight.com/doi/abs/10.1108/00400910610692606 (Accessed: 26 September 2018).

Vu, T.T. and Dall'Alba, G. (2014) 'Authentic Assessment for Student Learning: An ontological conceptualisation.' Educational Philosophy and Theory, 4(7), 778-791. Available at: https://www.tandfonline.com/doi/full/10.1080/00131857.2013.795110 (Accessed: 26 September 2018).

Whitelock, D. and Cross, S. (2011) Academics' understanding of authentic assessment.International Computer Assisted Asessment Conference. Available at: https://core.ac.uk/download/pdf/82962493.pdf (Accessed: 03 December 2017).

Wickramasinghe, V. and Perera, L. (2010) 'Graduates' university lecturers' and Employers' perception towards employability skills.' Education and Training, 3(3), 226-244. Available at: https://www.emeraldinsight.com/doi/abs/10.1108/00400911011037355 (Accessed: 26

September 2018). 
Wong, P., Ho, Y. and Singh, A. (2007) 'Towards an "Entrepreneurial University" Model to Support Knowledge-Based Economic Development: The Case of the National University of Singapore.' World Development, 35(6), 941-958. Available at:

https://www.sciencedirect.com/science/article/pii/S0305750X07000381 (Accessed: 26 September 2018) 